\title{
Scrap the carbon tariff
}

\author{
CATHERINE IZARD, CHRISTOPHER WEBER AND SCOTT MATTHEWS
}

\section{Despite their political popularity, carbon tariffs will be next to impossible to implement effectively, and as such will do little to solve the climate problem.}

n every US climate policy negotiation
thus far, a major sticking point
has been the issue of economic
competitiveness. If the US, or indeed any country, independently imposes a price on carbon - through a cap-and-trade system or a carbon tax, for example - domestic industries automatically face higher costs than their international peers and could be at a competitive disadvantage. Rather than pay these costs, of course, US industry could relocate to countries without mandatory emissions targets. This 'carbon leakage' could cost the US jobs while failing to reduce global emissions, a lose-lose scenario.

For the majority of US industry, the introduction of climate policy would have a negligible economic impact. There are exceptions, however, most notably energy-intensive industries such as steel and cement. Fortunately, several policy mechanisms can be used to protect their competitiveness. The proposed US climate bill, America's Clean Energy and Security $\mathrm{Act}^{1}$, uses two: first, the bill aims to rebate the increased costs of carbon emissions to energy-intensive industries through free allocation of emissions allowances. Second, US industries that import energy-intensive goods from countries without a price on carbon are required to purchase emissions allowances for those goods equal to what they would have paid had the imports been manufactured domestically. This tariff, a type of border tax adjustment, ensures that importers do not gain a competitive advantage over other domestic industries. The idea of implementing border adjustment mechanisms is now gaining popularity in the European Union, where France and Germany argue it would protect domestic industry if other nations do not agree to cut their emissions.

But there are numerous arguments against implementing carbon tariffs: they may trigger a trade war with damaging consequences for domestic industry; they target emerging economies whose cooperation is vital for global climate policy; they protect only industry on the domestic

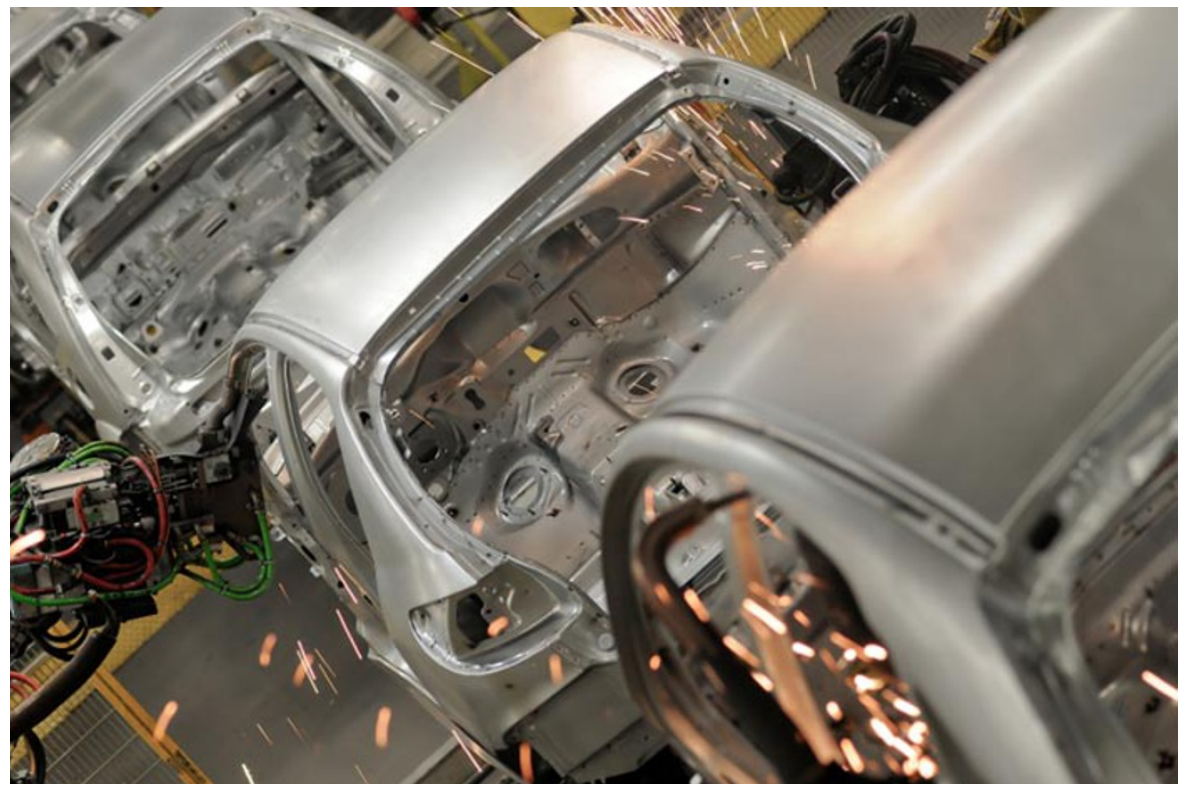

An estimated 60 per cent of the steel imported annually into the United States is in finished goods, such as cars.

market; and according to the World Trade Organization ${ }^{2}$ they may be illegal, depending on how they are implemented. These thorny issues have been discussed at length elsewhere ${ }^{3,4,5}$. Supporters of carbon tariffs claim that they have two main advantages: first, they protect domestic industry from competitive disadvantage. Second, because the tariffs apply only to countries without a price on carbon, they are a 'stick' to motivate other countries to legislate climate policy. Surprisingly, given the complications associated with a carbon tariff, few have asked whether the arguable advantages can ever be realized. Because of the impossibility of designing and implementing an effective tariff, we argue that they cannot.

\section{FATAL FLAWS}

There are two designs of carbon tariff, depending on what types of products are included. The simplest covers only primary energy-intensive materials, such as steel beams or plate glass. A comprehensive tariff would cover energy-intensive materials in all forms, including those embedded in finished goods such as the steel in a car or the aluminium in a can of soda. A hybrid approach, which covers only some categories of embedded materials, can also be applied. For example, the tariff in the proposed US climate bill covers all energy-intensive raw materials but only those finished goods that contain a 'substantial' amount of energyintensive materials.

Unfortunately, all of these approaches have fatal flaws. Applying the tariff to only raw materials is the least effective means of reducing emissions, because the majority of energy-intensive imports are in finished products. For example, only 40 per cent of US steel imports are in the form of raw steel. The remaining 60 per cent are imported as components in the billions of finished goods - such as home appliances and cars - that US consumers and businesses 
purchase annually ${ }^{6}$. With a tariff that covers only raw materials, the price of an imported finished product would not reflect the true cost of its emissions. Although this type of tariff can level the playing field for producers of raw materials, it would disadvantage US manufacturers of finished goods whose foreign competitors could buy cheaper raw materials. Thus, the simple tariff merely shifts the problem down the supply chain from producers of raw materials to manufacturers of finished goods.

The other principal approach - a tariff on all raw materials and finished products - fixes this problem by protecting domestic industry all along the supply chain. In this case, imported finished products would not have an advantage over their domestic counterparts, because the true cost of the products' emissions would be covered regardless of their origin. This fix, however, would be virtually impossible to implement because it requires two hard-to-obtain facts about every import: the amount of primary material embedded in the finished product and the emissions generated from the production of those embedded materials. To know the latter, is it necessary to know not only how much steel is in every imported car, for example, but also where and how every bit of that steel was made.

Since a tariff can be applied only to materials produced in countries without a price on carbon, knowing where and how a material was originally produced is critical to the efficacy and legality of the tariff. In a world of global commodity trade, though, a primary material may be transformed several times in different countries before becoming embedded in a finished product. For example, about 30 per cent of embedded steel imported to the US is produced in countries other than the country of final export ${ }^{5,6}$. Tracing the origin of primary materials back through the manufacturing process to the country of original production may be impossible and would certainly require great effort and cost to either regulators or private industry. Furthermore, to apply a tariff, not only would customs officials need to know where each and every bit of the embedded steel was originally produced, they would need to know the carbon emissions associated with each stage of production. The logistical challenges of such a scheme are clearly immense.

\section{CARRY A SMALL STICK}

As a stick to motivate other countries to adopt climate policies, a carbon tariff is unlikely to be effective because US imports are small relative to total production in these countries. For example, in 2007, although

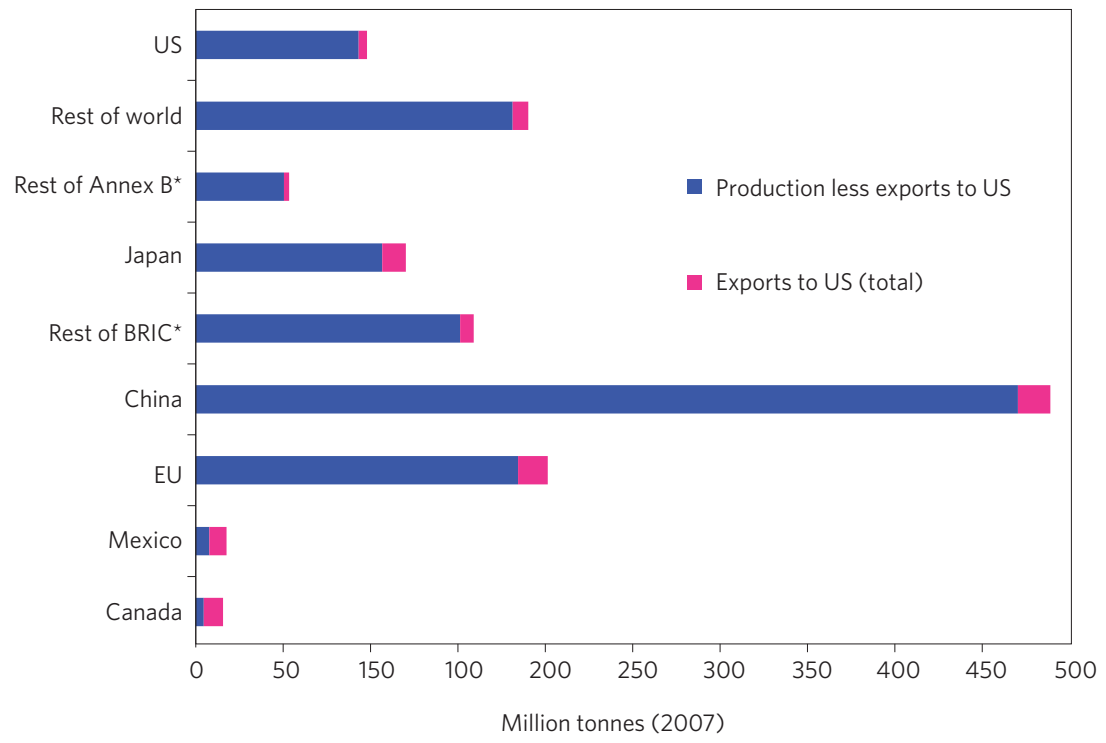

Figure 1 Small US influence. Bars show the proportion of total steel produced that is exported annually, both as raw material and embedded in goods, from different world regions to the United States. Rest of BRIC refers to the world's emerging economies, Brazil, India and Russia. Data for China is presented separately. Rest of Annex B countries refers to all other industrialized nations that have legally binding emissions reduction targets under the Kyoto Protocol.

the US imported about 50 million total tonnes of steel - in the form of raw and embedded materials - produced in tariffeligible countries, this represented only five per cent of total steel production in those countries ${ }^{6}$ (Fig. 1). Previous work has shown that the percentage of exports is also low for other raw materials ${ }^{3}$. A tariff on only five per cent of production is an insufficient stick to induce such countries to implement comprehensive climate change policy.

\section{Surprisingly, given the} complications associated with a carbon tariff, few have asked whether the arguable advantages can ever be realized.

Trade tariffs are emotionally appealing. Particularly in a recession, it is tempting to fall back on politically popular protectionist measures. But it may be impossible and would certainly be expensive to design a tariff that is effective in reducing emissions. Furthermore, the rationale that it would induce other countries to develop climate policies does not hold up to scrutiny.

The tariff in America's Clean Energy Security Act is the worst of both worlds, as it doesn't cover all embedded materials - and is therefore not optimally designed to address the climate problem - but covers enough embedded materials to make it virtually impossible to implement. Especially given that other measures exist to protect domestic industry, such as the proposed carbon-allowance rebates, the marginal benefits of implementing a carbon tariff do not balance the risks - most notable of which are the potential trade wars and the possibility of supplying ammunition to developing countries for refusing domestic action on climate change. The carbon tariff should be eliminated.

\section{Published online: 17 December 2009}

\section{doi:10.1038/climate.2010.132}

\section{References}

1. America's Clean Energy and Security Act, H.R. 2454, 111th Congress (2009); http://bit.ly/4Krh4O

2. Trade and Climate Change (World Trade Organization and United Nations Environmental Programme, Geneva, 2009); http://bit.ly/7YKlu6

3. Houser, T., Bradley, R., Childs, B., Werksman, J. \& Heilmayr, R. Levelling the Carbon Playing Field (Peterson Institute for International Economics and World Resources Institute, Washington DC, 2008); http://bit.ly/6TXqpA

4. Weber, C. \& Peters, G. Energ. Policy 37, 432-440 (2009).

5. Zhang, Z. Energ. Policy 37, 5105-5112 (2009).

6. Izard, C. Designing an Effective Border Tax Adjustment: Is it Possible? Engineering and Public Policy White Paper (Carnegie Mellon University, Pittsburgh, Pennsylvania, 2009).

Catherine Izard, Christopher Weber and $H$. Scott Matthews are in the Department of Civil and Environmental Engineering at Carnegie Mellon University, Pittsburgh, Pennsylvania. Catherine Izard and $H$. Scott Matthews are also in the Department of Engineering and Public Policy at Carnegie Mellon University.

e-mail: cizard@andrew.cmu.edu 